\title{
Employees' Perception of Service Orientation- An Exploratory Study
}

\section{K K Govender}

Department of Business Management, University of Transkei

\section{ABSTRACT}

In a matched sample survey of bank employees and customers, it was found that the employees' perception of the service orientation [SERVOR] of the banks, is positively correlated with the customers' perception of their overall service quality [SQUAL]. Service firm managers should take note that in the absence of direct control of the service encounter, organizational practices and procedures that treat service as top priority, are also likely to succeed in delivering service of high quality.

JEL M 21

\section{INTRODUCTION}

Since services are intangible, it is difficult for management, employees and customers to assess service output and service quality. Consequently, an organization's overall service orientation is very important in shaping the frontline employees' attitude to the process and outcome of service delivery. Although it may be argued that there are certain similarities between the constructs "market orientation", "customer orientation" and "service orientation", it is necessary to stress that service orientation is a perceptual process regarding the whole organization, whereas customer orientation focuses on the individual employee and his/her behaviour towards the customer. Furthermore, market orientation is a much broader concept in terms of its antecedents and consequences than service or customer orientation (Jaworski and Kohli, 1993). However, some researchers, for example Kohli and Jaworski (1990) and Nel and Schreuder (1994), do point out that customer orientation is an element of marketing orientation.

Service orientation (for the purpose of this study) refers to the employees' perception of what is important to the organization regarding the service it provides. The association between the employees' perception of the service orientation of their organization, and the customers' perception of the overall 
service quality is therefore being explored in this paper.

\section{BRIEF LITERATURE REVIEW AND HYPOTHESIS}

Schneider, Gunnarson and Niles-Jolly (1994) assert that employees observe what happens to them and around them, and draw conclusions about the organization's priorities. Some researchers (Julian and Ramaseshan, 1994) claim that since service organization employees have face-to-face contact with customers, their work seems to result in increased stress and strain because employees try to meet conflicting demands from management and customers. Schneider and Bowen (1995) contend that management can potentially manage employee stress by establishing an environment in which employees' desires to provide good services are made easier and encouraged. Thus the service environment created in an organization, including how the service is delivered, is crucial for the service unit's effectiveness.

Gronroos (1990) argued that a service orientation enhances the functional quality dimension of customer-perceived quality, and it probably also supports the production of good technical quality. Since service quality is in the delivery, it is the interaction between the deliverer and the consumer that determines service quality for the consumer. Organizations can only indirectly control the interaction or "service encounter" because of the simultaneous nature of production and consumption. In the absence of direct control of the service encounter, it is therefore posited that the organizational practices and procedures that communicate service as top priority will succeed in delivering high quality service.

In order to explore the relationship between service orientation and quality, it is hypothesized that: The service orientation as perceived by the employees is positively correlated with the service quality as perceived by the customers of a firm.

\section{RESEARCH DESIGN}

\section{Sample and Sampling Procedure}

The survey was conducted among a random sample of 210 front-line employees and 1050 customers of three major commercial banks in South Africa. A combination of convenience and judgemental sampling was followed in selecting 210 front-line bank employees who had meaningful encounters with bank customers, to distribute the customer questionnaires. After being briefed 
about the research, branch managers were requested to distribute and collect the employee questionnaires during regular staff meetings.

The bank employees were requested to hand the questionnaire together with a covering letter explaining the purpose of the research, as well as stamped and self-addressed envelopes, to every third customer with whom they interacted for at least five minutes. This approach has also been reported in other studies (Danaher and Mattsson, 1993; Naumann and Giel, 1995).

\section{Research Instruments}

To measure the customers' perception of the service orientation, a 22-item, five point Likert scale with anchors of (5) strongly agree and (1) strongly disagree was developed based upon an adaptation of Kelley's (1987) scales. Kelley's (1987) scale in turn was developed around the exploratory research by Parasuraman, Zeithaml and Berry (1985).

Since some researchers like Babakus and Boller (1992), Buttle (1996) and Nel, Pitt and Berthon (1997) have uncovered certain deficiencies in the SERVQUAL (Parasuraman et al., 1988) scale, an alternative scale (named SQUAL), based on the 22 items of the SERVQUAL instrument, was used in this study. This scale combines expectations and perceptions into one measure by asking customers whether certain aspects of service quality exceeded or fell short of expectations. This approach has inter alia been recommended by Cronin and Taylor (1992).

Service customers were asked to rate each of the twenty-two items on a scale ranging from 1 (worse than expected) to 5 (better than expected). A 5-point scale was used in this study because the pre-test revealed that respondents could not make fine mental distinctions with respect to the object measurement. This strategy is supported by Parasuraman (1991) who asserts that for accurate measurement, a large number of scale positions are needed when a single-item scale is used, in contrast with a multiple-item scale as was used in this survey.

\section{Reliability and Validity of Measuring Instruments}

\section{Reliability}

Stepwise Reliability Analysis was performed on the various measuring instruments using the computer programme SAS PROC.CORR (SAS Institute, 1990). In Stepwise Reliability Analysis (SRA), individual items are deleted from the various measuring instruments if this improves the overall reliability of a particular measuring instrument as measured by its Cronbach's coefficient alpha (Cronbach, 951). The process was repeated until all the measuring instruments possessed an acceptable level of reliability. 
Due to the fact that the latent variables SERVOR and SQUAL had too many items, it was decided to reduce their number by averaging the individual measurements. The final SERVOR scale which comprised of 13 items was refined as follows: $\mathrm{SO} 1=(\mathrm{SO} 3+\mathrm{SO} 4+\mathrm{SO} 7) / 3 ; \mathrm{SO} 2=(\mathrm{SO} 8+\mathrm{SO} 9+$ $\mathrm{SO} 10) / 3 ; \mathrm{SO} 3=(\mathrm{SO} 11+\mathrm{SO} 12+\mathrm{SO} 16) / 3 ; \mathrm{SO} 4=(\mathrm{SO} 17+\mathrm{SO} 18+\mathrm{SO} 21+$ $\mathrm{SO} 22) / 4$. The final SQUAL instrument which comprised of 16 items was refined as follows: $\mathrm{SQ1}=(\mathrm{SQ} 3+\mathrm{SQ} 6+\mathrm{SQ} 7+\mathrm{SQ} 8) / 4 ; \mathrm{SQ} 2=(\mathrm{SQ} 9+\mathrm{SQ} 11+$ $\mathrm{SQ} 12+\mathrm{SQ} 13) / 4 ; \mathrm{SQ} 3=(\mathrm{SQ} 14+\mathrm{SQ} 15+\mathrm{SQ} 16+\mathrm{SQ} 17) / 4 ; \mathrm{SQ} 4=(\mathrm{SQ} 18+$ $\mathrm{SQ} 19+\mathrm{SQ} 20+\mathrm{SQ} 21+\mathrm{SQ} 22) / 5$.

The SERVOR scale retumed a Cronbach alpha of 0.908 and the SQUAL scale was 0,961 . Since an instrument which produces a coefficient of reliability of at least 0.7 is favoured by most social scientists (Bless and Higson-Smith, 1995), the instruments used in this study were thus fairly reliable.

\section{Validity}

After determining the Cronbach's coefficients alpha, Stepwise Exploratory Factor Analysis (Wille, 1996) was performed to ascertain the discriminant and construct validity of the measuring instruments. In each step of the analysis, BMDP4M (Frane, Jennrich \& Sampson, 1993) was used to perform a maximum likelihood factor analysis with a direct quartimin rotation (Jennrich \& Sampson, 1966) of the unrotated factor matrix. It is evident from Table 1 that the measuring instruments had acceptable levels of discriminant and construct validity, since they load heavily with loadings above 0.4 (Rummel, 1967) on one factor only.

Table 1 Rotated Factor Loadings

\begin{tabular}{|c|c|c|}
\hline Items & $\begin{array}{c}\text { Factor 1 } \\
\text { Service quality }\end{array}$ & $\begin{array}{c}\text { Factor 2 } \\
\text { Service orientation }\end{array}$ \\
\hline SQ1 & $0.907^{* *}$ & 0.041 \\
\hline SQ2 & $0.886^{* *}$ & 0.022 \\
\hline SQ3 & $0.960^{* *}$ & -0.060 \\
\hline SQ4 & $0.910^{* *}$ & 0.019 \\
\hline SO1 & -0.085 & $0.866^{* *}$ \\
\hline SO2 & 0.028 & $0.740^{* *}$ \\
\hline SO3 & 0.112 & $0.884^{* *}$ \\
\hline SO4 & 0.070 & $0.858^{* *}$ \\
\hline
\end{tabular}

** : a loading above 0.4 was considered significant 
Data Analysis

The computer programme SAS PROC.CORR (SAS Institute, 1990) was used to assess the reliability of the research instruments, as well as to perform initial data analysis. The validity of the measurements was determined by use of the computer programme BMDP4M (Frane, Jennrich \& Sampson, 1993). To empirically evaluate the hypothesized relationship, the computer programme RAMONA (Brown and Mels, 1990) was used.

\section{FINDINGS, DISCUSSION AND RECOMMENDATIONS}

The three-month survey yielded 104 employee and 200 customer responses, representing a response rate of $49.5 \%$ for the employees and $19 \%$ for the customers. However, only 50 employee responses could be matched with 190 customer responses.

In Table 2, it appears that the overall mean and standard deviation scores were 4.269 and 0.470 respectively. Considering that a five-point scale was used, it may be assumed that the 104 employees perceived their organization as being highly service-oriented.

\section{Table 2 Mean and Standard Deviation Scores for Servor}

\begin{tabular}{|c|c|c|c|}
\hline Item & & $\begin{array}{c}\text { Mean } \\
{[n=104]}\end{array}$ & $\begin{array}{l}\text { Standard } \\
\text { Deviation }\end{array}$ \\
\hline SOI & $\begin{array}{l}\text { Staff should ensure that customers appreciate the } \\
\text { service provided }\end{array}$ & 4.423 & 0.867 \\
\hline $\mathrm{SO} 2$ & $\begin{array}{l}\text { Staff should use language which the customer can } \\
\text { understand }\end{array}$ & 4.509 & 0.750 \\
\hline $\mathrm{SO} 3$ & $\begin{array}{l}\text { Customers should be informed beforehand how } \\
\text { much the service will cost }\end{array}$ & 4.413 & 0.770 \\
\hline $\mathrm{SO} 4$ & It is important to honour promises to customers & 4.644 & 0.520 \\
\hline SOS & $\begin{array}{l}\text { Customers should be informed about what alternate } \\
\text { services are available }\end{array}$ & 4.596 & 0.566 \\
\hline SO6 & It is important to have convenient operating hours & 4.000 & 0.903 \\
\hline SO7 & $\begin{array}{l}\text { Employees should always be polite and friendly to } \\
\text { customers }\end{array}$ & 4.682 & 0.728 \\
\hline SO8 & $\begin{array}{l}\text { It is important to have up to date equipment so as } \\
\text { to provide good service }\end{array}$ & 4.625 & 0.753 \\
\hline
\end{tabular}




\section{Table 2 continued}

\begin{tabular}{|ll|c|c|}
\hline Item & $\begin{array}{c}\text { Mean } \\
\text { [n=104] }\end{array}$ & $\begin{array}{c}\text { Standard } \\
\text { Deviation }\end{array}$ \\
\hline SO9 $\quad \begin{array}{l}\text { It is important to keep the customer's best interest } \\
\text { at heart }\end{array}$ & 4.577 & 0.569 \\
\hline SO10 & $\begin{array}{l}\text { The training and preparation of the employees are } \\
\text { important }\end{array}$ & 4.519 & 0.995 \\
\hline SO11 & Dependable service performance is important & 4.519 & 0.750 \\
\hline SO12 & Consistent service performance is important & 4.548 & 0.761 \\
\hline SO13 & Prompt service by staff is stressed & 4.317 & 1.017 \\
\hline SO14 & Convenient service locations are important & 4.327 & 0.675 \\
\hline SO15 & The appearance of employees is important & 4,519 & 0.682 \\
\hline SO16 & Employee honesty is stressed & 4.567 & 0.707 \\
\hline SO17 & A reputation for good service is emphasized & 4.606 & 0.614 \\
\hline SO18 & The development of customer confidence in the \\
$\quad$ service is stressed & 4.375 & 0.791 \\
\hline SO19 & Individual customer attention is stressed & 4.298 & 0.846 \\
\hline SO20 & A nice atmosphere for service is stressed & 4.240 & 0.876 \\
\hline SO21 & Customers should feel free to discuss their needs & 4.490 & 0.710 \\
\hline SO22 & The confidentiality of the service is stressed & 4.519 & 0.750 \\
\hline
\end{tabular}

The PROC.CORR procedure using the SAS computer programme (SAS Institute, 1990) was also used to determine Spearman's correlation coefficient. The resulting correlation coefficient $(r=0.4040)$ implied that SERVOR is positively correlated with SQUAL. Furthermore, as reflected in Figure 1, the employees' perception of the service orientation of the banks is positively associated with the customers' perception of the overall service quality $(0.149$; p <0.05). This implies that when employees perceive that the banks are supportive of customer service, this will be reflected in their contact with customers, who then experience service of high quality. Thus the data supports the hypothesis.

The findings of this exploratory study are supported by Gronroos (1990) who argued that a strong service orientation is likely to lead to higher quality in service delivery, which in turn may well lead to higher perceived service quality from the customer's point of view too. Schneider and Bowen (1995) also maintained that customer service thrives in organizations which are perceived by employees as being service-oriented. 
Figure 1 Empirical Evaluation of Hypothesized Model

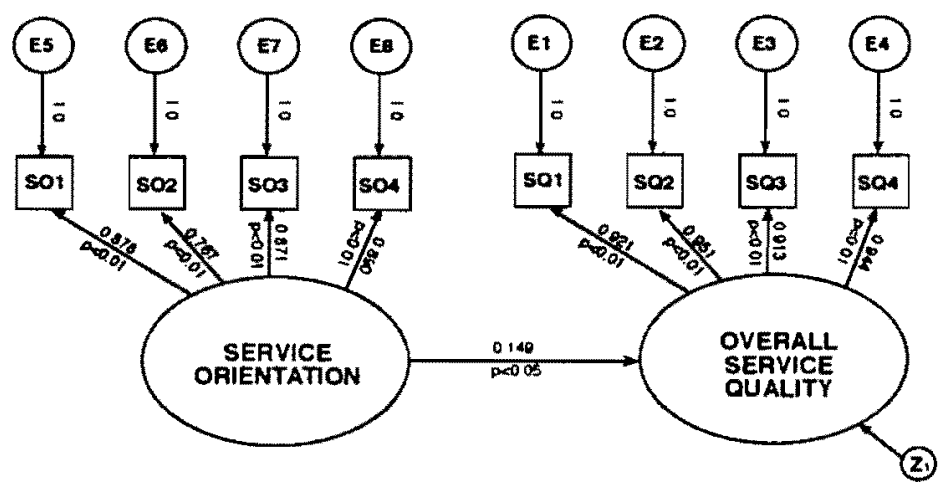

Schneider et al. (1994) also assert that the service atmosphere does impact on the performance and job satisfaction of employees. Thus Houston (1994) suggests that there is a need to manage the service environment in order to make the form a pleasant place to work.

Unlike the earth's atmosphere, the atmosphere of a work situation can be controlled; it can be improved, or worsened, by the actions of a firm's leaders and employees. A service orientation characteristic of a service culture, may well improve the service quality as perceived by customers.

In an effort to better manage the organization, service providers need to ask the following questions: How do employees see the organization? Are they clear about their role within the organization? Are they experiencing any stress from conflicting demands by management and customers?

\section{LIMITATIONS AND FUTURE RESEARCH}

Due to the research method used, namely mail survey, the tests of significance involving the matched employee-customer data were limited to 50 employees and 190 customers. Given an adequate research budget, customers could be interviewed immediately after their service encounter. However, this method may also not be very successful, because customers who have spent time in the bank queues may not be willing to be interviewed as well. 
From a methodological point of view, the data in this study were obtained from front-line employees and customers. Future research may also include backoffice staff. Furthermore, to increase the generalizability of the findings, future research might involve the replication of this study in a variety of service settings, industries and organizations. It would also be interesting to ascertain how customers view the service organization and compare this with the views of employees.

\section{REFERENCES}

1 BABAKUS, E. and BOLLER, G.W. (1992) "An Empirical Assessment of the SERVQUAL Scale", Journal of Business Research, 24(2): 253-68.

2 BLESS, C. and HIGSON-SMITH, C. (1995) Fundamentals of Social Research Methods: An African Perspective, 2nd ed. Kenwyn, Cape Town: Juta.

3 BUTTLE, F. (1996) "Is there a Role for Expectations in SERVQUAL?" Working Paper No. 294, UK: Manchester Business School.

4 CRONBACH, L.J. (1951) "Coefficient Alpha and the Internal Structure of Tests", Psychometrika, 16(3): 297-334.

5 CRONIN, J.J., JR. and TAYLOR, S.A. (1992) "Measuring Service Quality: A Re-examination and Extension", Journal of Marketing, 56; 55-68.

6 DANAHER, P.J. and MATTSON, J. (1994) "Customer Satisfaction during the Service Delivery Process", European Journal of Marketing, 28(5): 5-16.

7 FRANE, J.; JENRICH, R.I. and SAMPSON, P.F. (1990) "4M-Factor Analysis." In Dixon, W.J. et al., (eds.). BDMP Statistical Software Manual, Vol. 1, Berkeley: University of California.

8 GRONROOS, C. (1990) Service Management and Marketing. Managing the Moments of Truth in Service Competition. Massachusetts: Lexington Books.

9 HOUSTON, B.A. (1994) "Supervisors Matter More Than You Think: Components of a Mission-Centred Organizational Climate", Hospitality and Health Services Administration, 39(4): 7-23.

10 JAWORSKI, N.J. and KOHLI, A.K. (1993) "Marketing Orientation: Antecedents and Consequences", Journal of Marketing, 57(3): 53-70.

11 JENRICH, R.I. and SAMPSON, P.F. (1966) "Rotation of Simple Loadings", Psychometrika, 31: 313-23.

12 JULIAN, C.C. and RAMASESHAN, B. (1994) "The Role of CustomerContact Personnel in the Marketing of a Retail Bank's Services", International Journal of Retail and Distribution Management, 22(5): 15-28.

13 KELLEY, S.W. (1987) "Managing Service Quality: The Organizational Socialization of the Service Employee and Service Customer", 
Unpublished DBA dissertation, Kentucky: University of Kentucky.

14 KOHLI, A., and JAWORSKI, B. (1990) "Market Orientation: The Construct, Research Propositions and Managerial Implications", Journal of Marketing, 54 (April).

15 NAUMAN, E. and GIEL, K. (1995) Customer Satisfaction Measurement and Management: Using the Voice of the Customer. Cincinnati, Ohio: Thompson.

16 NEL, M. and SCHREUDER, A. (1994) "MARKOR: A Multiple Item Scale for the Measurement of Market Orientation." Paper delivered at the South African Institute of Management Scientists Conference, Belville, Cape Town.

17 NEL, D.; PITT, L.F. and BERTHON, P.R. (1997) "The SERVQUAL Instrument: Reliability and Validity in South Africa", South African Journal of Business Management, 28 (3):113-22.

18 PARASURAMAN, A., ZEITHAML, V.A., and BERRY, L.L. (1985) "A Conceptual Model of Service Quality and Its Implications for Future Research", Marketing Science Institute Repart 60-90. Cambridge, MA: Marketing Science Institute.

19 PARASURAMAN, A., BERRY, L.L. and ZEITHAML, V.A. (1988) "SERVQUAL: A Multiple-Item Scale for Measuring Consumer Perceptions of Service Quality", Journal of Retailing, 64(1):12-40.

20 PARASURAMAN, A. (1991) Marketing Research, 2nd.ed. Massachusetts: Addison-Wesley.

21 RUMMEL, R.J. (1967) "Understanding Factor Analysis", Journal of Conflict Resolution, 11: 444-80.

22 SAS Institute Inc. (1990) User's Guide Release 6.03, Cary, N.C.: SAS Institute Inc.

23 SCHNEIDER, B., GUNNARSON, S.K. and NILES-JOLLEY, K. (1994) "Creating the Climate and Culture of Success", Organizational Dynamics, 23(1): 17-30.

24 SCHNEIDER, B. and BOWEN, D.E. (1995) Winning the Service Game, Boston: Harvard Business School Press. 